\title{
Ultrafine particles (UFPs) from domestic wood stoves: genotoxicity in human lung carcinoma A549 cells
}

\author{
Laura Marabini $^{\mathrm{a}, *}$, Senem Ozgen ${ }^{\mathrm{c}, g}$, Silvia Turacchi ${ }^{\mathrm{a}}$, Stefania Aminti ${ }^{\mathrm{a}}$, Francesca Arnaboldi ${ }^{\mathrm{b}}$, \\ Giovanni Lonati $^{\mathrm{c}}$, Paola Fermo ${ }^{\mathrm{d}}$, Lorenza Corbella ${ }^{\mathrm{d}}$, Gianluigi Valli ${ }^{\mathrm{e}}$, Vera Bernardoni ${ }^{\mathrm{e}}$, \\ Manuela Dell'Acqua ${ }^{\mathrm{e}}$, Roberta Vecchi ${ }^{\mathrm{e}}$, Silvia Becagli ${ }^{\mathrm{f}}$, Donatella Caruso ${ }^{\mathrm{a}}$, Galli L. Corrado ${ }^{\mathrm{a}}$, \\ Marina Marinovich ${ }^{\mathrm{a}}$
}

a Department of Pharmacological and Biomolecular Sciences, Università degli Studi di Milano, Via Balzaretti 9, 20133, Milan, Italy

b Department of Biomedical Sciences for Health, Lab of Structural and Ultrastructural Morphology, Università degli Studi di Milano, Milan, Italy

${ }^{c}$ Department of Civil and Environmental Engineering, Politecnico di Milano, Milan, Italy

d Department of Chemistry, Università degli Studi di Milano, Milan, Italy

e Department of Physics, Università degli Studi di Milano, Milan, Italy

f Department of Chemistry "Ugo Schiff”, Università degli Studi di Firenze, Sesto Fiorentino, Italy

${ }^{\mathrm{g}}$ LEAP Energy and Environment Laboratory, Piacenza, Italy

\begin{abstract}
A B S T R A C T
In this paper, results on the potential toxicity of ultrafine particles (UFPs $d<100 \mathrm{~nm}$ ) emitted by the combustion of logwood and pellet (hardwood and softwood) are reported. The data were collected during the TOBICUP (TOxicity of BIomass COmbustion generated Ultrafine Particles) project, carried out by a team composed of interdisciplinary research groups. The genotoxic evaluation was performed on A549 cells (human lung carcinomacells) using UFPs whose chemical composition was assessed by a suite of analytical techniques. Comet assay and $\gamma-\mathrm{H} 2 \mathrm{AX}$ evaluation show a significant DNA damage after $24 \mathrm{~h}$ treatment. The interpretation of the results is based on the correlation among toxicological results, chemical-physical properties of UFPs, and the type and efficiency conditions in residential pellet or logwood stoves.
\end{abstract}

\section{Introduction}

An increasing sensitivity for personal wellness and a greater attention for environment brings scientists to develop new alternative energetic sources for residential heating. After having used fossil fuels for years, currently wood has come back as fuel for domestic heating. Fossil fuels are highly performing energetic sources for residential combustion, but they are not renewable and the toxic effects of their emissions on environment and human health are well known [1].

The adverse impact on health of biomass combustion has also been demonstrated by the occurrence of respiratory symptoms and respiratory disease among population living in areas with a high wood smoke contribution to environment pollution [2,3].

Epidemiological studies have shown that particles with an aerodynamic diameter beneath $2.5 \mu \mathrm{m}$ (PM2.5), are able to exacerbate inflammatory diseases as asthma or acute bronchitis; they may cause acute heart attacks or contribute to lead to chronic diseases as diabetes or cardiovascular diseases or may have a role in pulmonary cancer
[4-6]. Wood smoke may cause health effects similar to particulate matter from other sources and in particular to traffic-emitted particles [7].

In vitro and in vivo studies are mainly conducted with PM2.5 particles. In vitro the release of pro-inflammatory cytokines, oxidative stress and DNA damage was highlighted $[8,9]$. It was demonstrated that nanoparticles are able to induce the production of inflammatory proteins in alveolar macrophages and epithelial cells including cytokines and chemokines [10]. Among the pro-inflammatory mediators the measurement of interleukin-8 (IL-8) is of particular relevance as this chemokine is a neutrophil attractor and the cause of a possible tissue damage. Chemical-physical properties of ultrafine particles (UFPs, i.e. particles with aerodynamic diameter lower than $100 \mathrm{~nm}$ ) depend on the nature of the substances forming the core of particles as well as on the different chemical components that enrich the large specific surface area of particles. In fact, ultrafine particles, emitted during wood combustion from their production in stoves to human alveolar cells could be enriched of combustion by-products, such as polycyclic

\footnotetext{
* Corresponding author at: Department of Pharmacological and Biomecular Sciences, Università degli Studi di Milano, Via Balzaretti, 9, 20133 Milano, Italy.

E-mail address: laura.marabini@unimi.it (L. Marabini).
} 
aromatic hydrocarbons (PAHs), ions, heavy metals, and other oxidant components present in the air. These particles can also undergo a chemical modification by UVA and B - radiations. We have previously demonstrated that various type of pellets can generate biologically active fine particulate matter [11].

More recently, in vivo data have shown a variety of responses to 3-4 h exposure to wood smoke particles in healthy humans evidencing an enhanced DNA repair activity while showing minor and limited systemic effects related to oxidative stress and inflammation. Other experimental studies have reported that after short term exposure to PM1 minor proinflammatory lymphocytic and mast cell effects in the bronchial biopsies and soluble inflammatory markers have been detected [7,12-15].

We recently published the effect of the UFP samples collected from stoves on the induction of the pro-inflammatory cytokine interleukin-8 in two human cells lines (A549 and THP-1) and in human peripheral blood leukocytes [16]. The results showed higher THP-1 cells sensitivity than the A549 cells and, in particular, a greater effect of the particles obtained from the combustion of wood compared to softwood (fir) pellets. This effect is likely due to significant differences in levoglucosan quantities rather than from the contribution of other components.

The aim of the present research was to study the mode of action and the potential toxicological effect induced by ultrafine particles produced by the combustion of two widespread types of firewood (beech and fir) in state-of-the-art commercial pellet and logwood room-heaters on human type II alveolar cells (A549 cell lines). In particular, in this article we report the biological effects of UFPs obtained utilizing the burning process already standardized in a previous published paper. We detect the UFP intracellular disposition on the surface or inside cells by Transmission Electron Microscopy (TEM), measure the oxygen and nitrogen intracellular reactive species, and assess the potential genotoxic damage by two predictive tests (Comet assay and immunostaining of $\gamma \mathrm{H} 2 \mathrm{AX}$ histone proteins). Interpretation of data is based on the correlation among the toxicological results and the chemical-physical properties of UFPs generated from the two room-heaters.

The UFP emissions and the chemical composition are known to be strictly related to the operational combustion conditions in the residential heating appliance [17]; it is noteworthy that even an appliance operating under optimal conditions may produce high levels of UFP [18]. For this reason, simulating the real-world behaviour of the appliance gains uttermost importance in the view of the increased exposure of the population living nearby UFP sources with limited dispersion due to the low height of emission. In order to reproduce the real-world quality of the emissions from the actual usage of residential heating appliances, the UFP sampling strategy in the present study followed an approach previously successfully tested in the domestic combustion appliance testing [19].

\section{Materials and methods}

\subsection{Tested stoves and combustion cycle}

Two state-of-the-art room-heaters (a pellet stove of $11 \mathrm{~kW}$ and a log wood stove of $8 \mathrm{~kW}$ ) were tested under simulated real-world loading and operation pattern in the Laboratory for Energy and Environment of Piacenza, Italy (LEAP) facility (www.leap.polimi.it). Softwood (fir wood) and hardwood (beech wood) biomass fuel was used for the combustion experiments. Detailed description of the experiments are published elsewhere [20]. A brief description as well as the experimental setup (Fig. SM1 in the Supplementary Material) are available in the Supplementary Material.

\subsection{UFP sample collection for chemical characterization and toxicological analysis}

Three multistage impactors operating in parallel sampled the flue gas. All UFP samples collected on two lower impaction stages and the back-up filter were weighed and then characterized for their chemical composition so that elements, water soluble ions, total carbon, polycyclic hydrocarbons and anhydrosugars (tracers for wood combustion) were quantified. Ultrafine particle samples detached from aluminium substrates were sent to toxicological determination. Further details on the experimental methods are available in the Supplementary Material and in Corsini et al. [16,21].

\subsection{Cell line and cell culture}

The human cell line used in the present study included A549, an adenocarcinoma human lung alveolar basal epithelial cell line, obtained from Zooprofilattico Institute (Brescia, Italy). Cells were grown in T-75 culture flasks in a humidified atmosphere of $5 \% \mathrm{CO}_{2}$ at $37^{\circ} \mathrm{C}$ and were maintained in proliferation medium RPMI-1640, containing $10 \%$ fetal bovine serum (FBS), $1 \%$ penicillin-streptomycin (P/S) $(100$ $\mathrm{IU} / \mathrm{mL}$ penicillin and $100 \mathrm{IU} / \mathrm{mL}$ streptomycin) $0.008 \%$ pyruvic acid and $0.024 \%$ Glutamine. Medium was changed after a growth period of 2 days and the cells split (1:15) every 5 days.

\subsection{UFPs sample extraction for biological studies and treatments}

UFPs to be used in toxicological tests were detached from filters by sonication for $60 \mathrm{~min}$ in ethanol and water (50:50) solution. After UFPs detachment, samples were evaporated at $37{ }^{\circ} \mathrm{C}$ using an evaporator (Syncore Buchi) at low pressure $(25 \mathrm{mpsi})$ for $24 \mathrm{~h}$. Extracted UFPs were suspended in phosphate-buffered saline (PBS, $1 \mathrm{mg} / \mathrm{mL}$ ). Stock solutions were vortexed for $30 \mathrm{~s}$ immediately before cell exposure. In order to evaluate the contribution of the blank, unexposed filters were also extracted under the same conditions, no changes in any of the parameters measured compared to control cells were observed (data not shown).

Stock solutions of our samples were vortexed for $30 \mathrm{~s}$ at $50 \mathrm{~Hz}$ (Ultrasonicatore UP50H Compact Lab Homogenizer, Hielscher ultrasonic $\mathrm{GmbH}$; Telton, Germany), for three times, taking the sample in ice, immediately before cell exposure. A549 cells were treated with UFP samples at $25-100 \mu \mathrm{g} / \mathrm{mL}$ concentrations for $24 \mathrm{~h}$.

\subsection{Transmission electron microscopy (TEM) to the internalization}

The UFP intracellular arrangement in cells was evaluated by transmission electron microscopy analysis. The cells were seeded in Petri $35 \mathrm{~mm}$ with complete medium for $24 \mathrm{~h}$ to obtain the confluence, when they were exposed to UFPs, suspended in medium at the concentration of $50 \mu \mathrm{g} / \mathrm{mL}$ for $24 \mathrm{~h}$. Afterwards, UFP suspensions were removed and cells were washed with PBS, $1 \mathrm{~mL}$. Then, cells were detached from Petri and centrifuged at $800 \mathrm{rpm}$ for $10 \mathrm{~min}$; the pellet was suspended in Sørensen buffer $(0.1 \mathrm{M})$ and fixed for $2 \mathrm{~h}$ with $3 \%$ glutaraldehyde in Sørensen buffer $0.1 \mathrm{M}$ at pH 7,4. The fixed pellets were washed with Sørensen buffer for 3 times and finally post- fixed with $1 \%$ osmium tetroxide for $1 \mathrm{~h}$ and then further post-fixed in $1 \%$ uranyl acetate. Then, the pellets were dehydrated in graded aceton series before being transferred into Durcupan (Durcupan, Fluka) to solidify the cell pellets. Ultrathin sections were made with a Leika ultramicrotome, stained with lead citrate. Finally, the sections were observed with a CX100 transmission electron microscope (Jeol, Tokio).

\subsection{Cytotoxicity assay in vitro}

Cytotoxicity of the control and treated cells was assessed with MTT assay, by measuring mitochondrial reduction of the tetrazolium salt 3(4,5-dimethylthiazol-2-yl)-2,5-diphenyltetrazolium bromide (MTT) to (aqueous insoluble product) formazan by succinic dehydrogenase.

Cells were cultured in 96-well plates, treated with medium (control) and increasing concentrations of UFP suspension for $24 \mathrm{~h}$. The medium containing UFPs was then removed and washed 3 times with $0.1 \mathrm{~mL}$ of 
PBS. Next, $0.2 \mathrm{~mL}$ of RPMI 1640 medium containing the dye MTT $(0.5 \mathrm{mg} / \mathrm{mL})$ was added. After incubation for $3 \mathrm{~h}$ at $37^{\circ} \mathrm{C}$, the medium with dye was removed and washed for $0.1 \mathrm{~mL}$ of PBS. $0.2 \mathrm{~mL}$ of DMSO was carefully added to lyse the cells. The plates were shaken for $10 \mathrm{~min}$, and the absorbance for each well was read in a spectrophotometer at $450 \mathrm{~nm}$ (Multilabel counter Victor Wallac 1420). The values were expressed as percentages of MTT reduction compared to the control.

\subsection{Alkaline single-cell gel electrophoresis (SCGE, comet assay, $p H>13$ )}

Cells embedded in agarose on a microscope slide were lysed with solution containing detergent and high salt to form nucleoids containing supercoiled loops of DNA. The DNA was allowed to unwind under alkaline conditions in the electrophoresis buffer. Following the unwinding, the DNA underwent electrophoresis at high $\mathrm{pH}(\mathrm{pH}>13)$, allowing fragmented DNA to migrate away from the nucleus. Once the slides were dry, they were stained with the DNA-specific fluorescent dye propidium iodide and were observed by fluorescence microscopy [22]. Images of the fluorescent stained cell nuclei were analyzed using TriTek Comet Score Imaging Software 1.5. Nucleoids were classified in five categories (A undamaged, B-D damaged, E ghost) on the basis of the area and intensity of the tail staining, and DNA damage quantified as the percentage DNA in the tail (\% DNA-Tail), Tail length (TL, $\mu \mathrm{m})$ and Tail Moment $(\mathrm{TM}=\%$ DNA-Tail $\times \mathrm{TL}, \mu \mathrm{m})$.

\subsection{Detection of $\gamma-H 2 A X$ foci}

After $24 \mathrm{~h}$ of treatment, A549 cells, grown on glass slides, were fixed in cold methanol for $10 \mathrm{~min}$. Cells were rehydrated in PBS $(3 \times 5 \mathrm{~min})$ and permeabilized in PBS containing 0.5\% Triton X-100 for 20 min. After blocking for $30 \mathrm{~min}$ in 3\% BSA in PBS, cells were incubated with mouse anti- $\gamma$-H2AX (Millipore, 1:150 in BSA 1\%) for $2 \mathrm{~h}$ at room temperature, and after PBS washing $(3 \times 5 \mathrm{~min})$ incubated with a secondary anti mouse Alexa Fluor 488 antibody (1:500 Life Tecnnology) for $1 \mathrm{~h}$ at room temperature. Nuclei were counterstained with DAPI (Vectasshield Mounting Medium). Images were acquired (60x) utilizing a Nikon Eclipse E600 equipped with a digital camera Axioplan (Nikon, Tokio, Japan). The number of $\gamma$-H2AX foci/nucleus was determined using the ImageJ software, and cells classified in three groups $(0-5,6-10,>10$ foci) according to the number of foci per nucleus [23].

\subsection{Oxygen (ROS) and nitrogen (RNS) radicals specie production}

ROS formation was quantified according to Wang et al. [24] with some modifications, using the cell-permeable, non-fluorescent probe $2^{\prime}, 7^{\prime}$-dichlorofluorescin diacetate (DCFDA), which was de-esterified intracellularly and turned to highly fluorescent $2^{\prime}, 7^{\prime}$-dichlorofluorescein upon oxidation. Cells were seeded in black 96-well plates, and incubated with $25 \mu \mathrm{M}$ DCFDA at $37^{\circ} \mathrm{C}$ for $30 \mathrm{~min}$. After incubation, culture medium was discarded, cells washed with PBS and fluorescence measured using a microplate reader (Multilabel counter Victor Wallac 1420, Perkin-Elmer, Monza, Italy) at $485 \mathrm{~nm}$ ex/530 nm em.

RNS formation was quantified using the cell-permeable, non- fluorescent probe DA-FM-DA (4-amino-5-methylamino- 2',7'-difluorofluorescein diacetate) [25]. Cells were seeded in black 96-well plates, incubated with $25 \mu \mathrm{M}$ DA-FM-DA at $37^{\circ} \mathrm{C}$ for $60 \mathrm{~min}$. After incubation medium culture was discarded, the cells were washed with PBS and fluorescence was measured using a microplate reader at $485 \mathrm{~nm} \mathrm{ex}$ / $530 \mathrm{~nm}$ em. The results were calculated as fluorescence units (FU)/ $\mu \mathrm{g}$ of total cell protein. Protein concentration was measured by the method of Lowry et al. [26], using bovine serum albumin as standard.

\subsection{Statistical analysis}

Triplicate experiments were performed with independent samples. The results were analyzed using ANOVA $t$-test to assess statistical significance, one-way or two-way ANOVA analysis followed by post-hoc Dunnett or Bonferroni tests for multiple comparisons. Results were considered statistically significant at $\mathrm{p}<0.05$. Analysis was carried out using the software package GraphPad Prism version 6.0. Statistical differences were considered at $\mathrm{p}<0.05$, $\mathrm{p}<0.01$ or $\mathrm{p}<0.001$ levels vs. the control group as indicated in the figures and captions. In the following, the results are expressed as means \pm standard deviation.

\section{Results}

\subsection{Links between the combustion conditions and the UFP composition}

The UFP composition data were pooled into four main categories, based on the appliance operation (i.e., continuous vs. batch-wise) and wood type (beech and fir wood): beech (BP) and fir (FP) pellets combustion in an automatic stove, and the batch-wise combustion of beech (BW) and fir (FW) log wood in the manually fed wood stove. Table 1 reports the emission background information and flue gas average characteristics (e.g., flue gas temperature, flue gas excess oxygen) during the tests. The UFP composition is summarized in Table 2.

The automatic air and fuel supply and the distinguishing trait of the pelletized fuel (i.e., low moisture and small feed size with respect to wood logs) in BP and FP tests favoured a more efficient combustion through optimal mixing of fuel and air. Hence, UFP samples from the pellet stove were mostly ash-related material. Water-soluble inorganic species (WSIS, both cations and anions) accounted for $37 \%$ and $39 \%$ of the UFP for BP and FP respectively. In both cases, $\mathrm{K}^{+}$and $\mathrm{SO}_{4}{ }^{-}$were the main constituents of the WSIS $\left(\mathrm{K}^{+}: 23 \%\right.$ in $\mathrm{FP}$ and $25 \%$ in $\mathrm{BP} ; \mathrm{SO}_{4}{ }^{-}$: $12 \%$ in $\mathrm{FP}$ and $9 \%$ in $\mathrm{BP}$ ). Other minor organic and inorganic ions contents (e.g., nitrite, nitrate, calcium, acetate, formate) were not different between the two type of pellets, except for a higher chloride content for FP tests. TC content of UFP from pellets combustion was higher for FP (13\%) than for BP (4\%). Trace amounts (about $100 \mu \mathrm{g} / \mathrm{g}$ ) of anhydrosugars (AS) and PAHs were observed for all pellet samples without a clear trend between the wood types. The investigated elements accounted on average about $1 \%$ of the UFP without a relevant difference between the two wood types. There was a great variability of the contributions of the various elements between the samples; however, $\mathrm{Zn}, \mathrm{Al}$, and $\mathrm{Fe}$ were the three dominant elemental species in all samples. $\mathrm{Zn}$ in particular was richer in FP.

The main differences between the wood log and the pellets burning

Table 1

Background emission and flue gas characteristics. (FP and BP: fir and beech pellet; FW and BW fir and beech wood).

\begin{tabular}{|c|c|c|c|c|c|c|c|c|c|}
\hline Test ID. & Fuel & $\begin{array}{l}\text { Operating } \\
\text { details }\end{array}$ & $\begin{array}{l}\text { number of UFP } \\
\text { samples }\end{array}$ & $\begin{array}{l}\text { sampling time } \\
\text { (min) }\end{array}$ & $\begin{array}{l}\text { fuel consumption } \\
(\mathrm{kg} / \mathrm{h})\end{array}$ & $\begin{array}{l}\text { flue gas temperature } \\
\left({ }^{\circ} \mathrm{C}\right)\end{array}$ & $\mathrm{O}_{2}(\% \mathrm{v})$ & $\begin{array}{l}\text { UFP (mg/ } \\
\left.\text { MJ }_{\text {out }}\right)\end{array}$ & $\mathrm{CO}\left(\mathrm{mg} / \mathrm{MJ}_{\text {out }}\right)$ \\
\hline FP & fir pellets & continuous & 5 & $209 \pm 28$ & $1.8 \pm 0.3$ & $204 \pm 19$ & $13.1 \pm 1.7$ & $29.7 \pm 15$ & $216 \pm 62$ \\
\hline BP & $\begin{array}{l}\text { beech } \\
\text { pellets }\end{array}$ & continuous & 3 & $186 \pm 8$ & $1.7 \pm 0.1$ & $191 \pm 7$ & $14 \pm 0.2$ & $25.2 \pm 4$ & $922 \pm 106$ \\
\hline FW & fir wood & batch-wise & 3 & $287 \pm 22$ & $2.1 \pm 0.2$ & $350 \pm 11$ & $10.9 \pm 1.1$ & $36.2 \pm 9$ & $4889 \pm 879$ \\
\hline BW & $\begin{array}{l}\text { beech } \\
\text { wood }\end{array}$ & batch-wise & 4 & $370 \pm 26$ & $1.9 \pm 0.2$ & $300 \pm 22$ & $14.5 \pm 1.5$ & $67.4 \pm 30$ & $2976 \pm 517$ \\
\hline
\end{tabular}


Table 2

UFPs composition (\%w)

\begin{tabular}{lllll}
\hline Test ID. & FP composition $(\% w)$ & & \\
& & BP & FW & BW \\
\hline TC & $12.7 \pm 1.6$ & $3.6 \pm 0.7$ & $48.8 \pm 9.2$ & $89.8 \pm 9.2$ \\
WSIC & $24.2 \pm 3.8$ & $26.6 \pm 7.7$ & $2.8 \pm 1.2$ & $0.9 \pm 0.3$ \\
WSIA & $15.3 \pm 2$ & $10.9 \pm 3.6$ & $4.9 \pm 2.3$ & $5.3 \pm 1.2$ \\
WSOA & $1.3 \pm 0.2$ & $1.5 \pm 0.6$ & $0.9 \pm 0.3$ & $0.9 \pm 0.4$ \\
AS & $0.01 \pm 0.01$ & $0.01 \pm 0$ & $7.23 \pm 0.63$ & $2.03 \pm 1.58$ \\
ELEM & $1.1 \pm 0.4$ & $0.8 \pm 0.3$ & $0.4 \pm 0.1$ & $0.5 \pm 0.2$ \\
PAH & $0.01 \pm 0.01$ & $0.01 \pm 0.01$ & $0.12 \pm 0.03$ & $3.24 \pm 0.63$ \\
\hline
\end{tabular}

$\mathrm{TC}=$ total carbon

WSIC $=$ water soluble inorganic cations $\rightarrow \Sigma(\mathrm{K}+, \mathrm{Ca} 2+, \mathrm{Na}+, \mathrm{NH} 4+, \mathrm{Mg} 2+)$

WSIA $=$ water soluble inorganic cations $\rightarrow \Sigma(\mathrm{Cl}-$, NO2-, NO3-, SO42-).

WSOA $=$ water soluble organic anions $\rightarrow \Sigma$ (formate, acetate, propionate, oxalate).

AS $=$ anhydrosugars $\rightarrow \Sigma$ (levoglucosan, mannosan, galactosan).

ELEM $=$ elements $\rightarrow \Sigma(\mathrm{Al}$, As, Ba, Cd, Co, Cr, Cu, Fe, Mn, Mo, Ni, P, Pb, Sr, Ti, V, Zn).

$\mathrm{PAH}=$ polycyclic aromatic hydrocarbons $\rightarrow \Sigma$ (3-ring isomers with molecular weight (MW) 178: phenantherene [Phe], anthracene [Ant], 4-ring isomers with MW 202: fluoranthene [Flu], pyrene [Pyr], 4-ring isomers with MW 228: benzo(a)anthracene [BaA], chrysene [Cry], 5-ring isomers with MW 252: benzo(b)fluoranthene [BbF], benzo (a)pyrene $[\mathrm{BaP}])$.

samples, was the higher presence of incomplete combustion products (mainly TC, PAH, AS). Lack of available oxygen in the high temperature zones in the chamber and low temperature combustion with excessive oxygen were the primary reasons for the increase of TC share in the UFP from wood $\log$ combustion (for $90 \% \mathrm{FW}$ and $49 \%$ for $\mathrm{BW}$ ). Levoglucosan was the most abundant AS (7\% for BW and $2 \%$ for FW) followed by mannosan and to a much lesser degree by galactosan. Levoglucosan content in UFP samples from BW tests characterized by lower temperatures and higher excess air was about 4 times higher than in FW samples. Samples from FW tests, on the other hand, characterized by intense combustion conditions (i.e., lowest excess oxygen and highest temperatures) contained about 30 times higher PAH than BW samples $(1 \mathrm{mg} / \mathrm{g}$ for BW and $32 \mathrm{mg} / \mathrm{g}$ for FW). PAH levels in wood samples were more than one-to-two orders of magnitude with respect to those of pellet samples. Moreover, the average PAH fingerprints of these samples shifted towards higher MW PAHs (Fig. SM2 in Supplementary Material). Elemental content of the UFP was about half that of pellet UFP with similar contribution for both wood types. As for the pellet UFPs, the three dominant elements were $\mathrm{Zn}, \mathrm{Al}$, and $\mathrm{Fe}$.

\subsection{Cellular uptake}

Intracellular accumulation of different UFPs was investigated by TEM observations of cells exposed to UFPs $(50 \mu \mathrm{g} / \mathrm{mL})$ for $24 \mathrm{~h}$. The particles were taken up by cells and were mainly entrapped in various cytoplasmic compartments (Fig. 1).

Control cells were all nucleated and with abundant mitochondria in the cytoplasm (Fig. 1A, asterisk). All the different kind of ultrafine particles were internalised by A549 cells, and appear aggregated in cluster. UFPs were never observed in nuclei but it may depend from observation time (data not showed).

Ultrafine particles originated from fir pellets combustion were exclusively localized in mitochondria as small aggregates (Fig. $1 \mathrm{~B}$, arrows), while those from beech pellets were found as big aggregates only in the cytoplasm (Fig. 1C, arrows). On the other hand, ultrafine particles originated from beech wood combustion in the wood stove were found in the cytoplasm (Fig. $1 \mathrm{D}$, arrows). They were also localized in correspondence of mitochondrial cristae (Fig. 1 D, asterisk and arrows).

\subsection{MTT test}

Cytotoxicity induced by UFP was evaluated by MTT assay. Each sample for logwood or pellets was tested at 50 and $100 \mu \mathrm{g} / \mathrm{mL}$. Results showed that all logwoods or pellet samples caused a mortality less than $40 \%$ at all tested doses. These results enabled the use of 50 and $100 \mu \mathrm{g} /$ $\mathrm{mL}$ concentrations for the subsequent genotoxicity experiments. The cytotoxicity increased with increasing doses. Significant differences compared to control samples were found for all samples with the exception of FP at $50 \mu \mathrm{g} / \mathrm{mL}$ that showed no relevant cytotoxicity (Fig. 2). The overall comparison pointed out a similar vitality for BP, FW and BW; a higher cytotoxicity was associated to FW combustion.

\subsection{Comet assay}

Among parameters describing DNA damage, Tail Length (TL) points out fragmentation of DNA running on electrophoretic field. TL data showed a marked and significant DNA damage by single- and doublestrand breaks (SSBs and DSBs, respectively) for all samples: pellets data doubled those of control cells and logwood data were twice the pellet data (except for BW50 that was comparable to pellets results) (Fig. 3).

\subsection{Gamma-H2AX assay}

$\gamma$-H2AX was investigated to study the induction of DNA breaks by UFP. This protein is phosphorylated after massive DSBs in DNA induced by oxidative stress or xenobiotic insults, and it is involved in DNA repair. The foci frequency and the percentage of various cell types are an index of DNA stress. All samples from logwood or pellet combustion were tested at $50 \mu \mathrm{g} / \mathrm{mL}$. No statistical difference was found among samples but all of them showed a significant increase in DNA DSBs compared to control in all foci groups (Figs. 4 and 5). Highest significant changes were observed in the percentage of cells with foci number $>10$, $(\mathrm{p}<0.01$ and $\mathrm{p}<0.001)$.

\subsection{Evaluation of intracellular reactive species of oxygen and nitrogen (ROS and RNS)}

The reactive species of oxygen and nitrogen are known to induce direct and indirect damage to DNA strands, proteins and cells membranes. A549 cells were treated withUFP concentrations of 50-100 $\mu \mathrm{g}$ / $\mathrm{mL}$.The production of ROS and RNS has been assessed at $24 \mathrm{~h}$ treatment when the UFP cell internalization was completed (Fig. 6). Then fluorescence has been pointed out at short times $(10,30,60 \mathrm{~min})$ of treatment to find out the early production of ROS/RNS after first contacts of UFP with cell membrane. No relevant production of ROS was observed after $24 \mathrm{~h}$ except for beech wood samples. The kinetics of formation of ROS (expressed as FU/ $\mu$ g proteins) indicated a peak between 10 and $30 \mathrm{~min}$, with an increasing statistical significance for pellet UFPs and kept up to $60 \mathrm{~min}$. The RNS peak, on the other hand, was evident after $10 \mathrm{~min}$ for all the treatments, but statistically significant at $24 \mathrm{~h}$ only for beech wood UFPs. (Figs. 6 and 7)

\subsection{UFP mass and energy-weighed toxicological responses}

Table 3 reports the toxicological responses relative to an equal UFPs mass dose. The minimum response is indicated with 1 . The same table presents also the responses weighed by the energy output of the appliances.

For a dose of $50 \mu \mathrm{g} / \mathrm{mL}$, the same amount of UFP caused minimum cytotoxicity for FP; other values were more than two folds higher: comparable values were observed between $\mathrm{BW}$ and $\mathrm{BP}$, whereas the highest cytotoxicity was observed for FW. No clear relationship was evident between the cytotoxicity and the UFP composition. Similar genotoxic response (tail length) was detected in all samples except FW. The enrichment of FW samples in PAHs pointed out these compounds as the potential genotoxic agent causing the initial DNA damage observed. Further investigation of genotoxicity (DSBs) revealed a comparable damage induced by all the samples with least damage caused by BW. No distinct association was found with the composition. ROS (after $1 \mathrm{~h}$ ) 

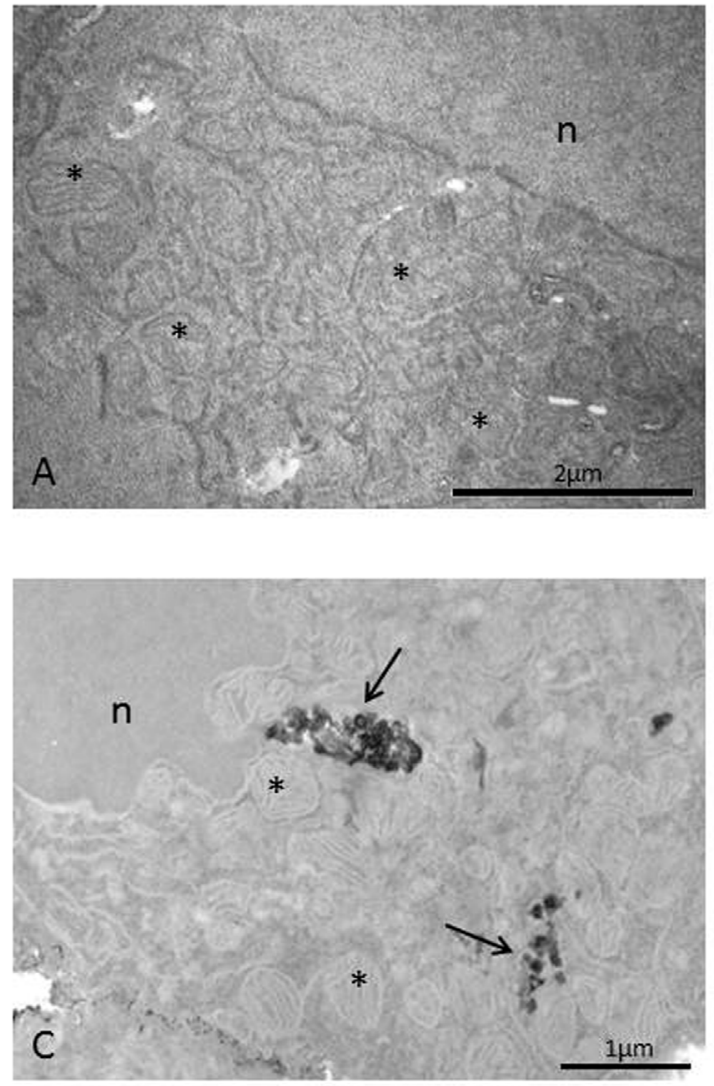
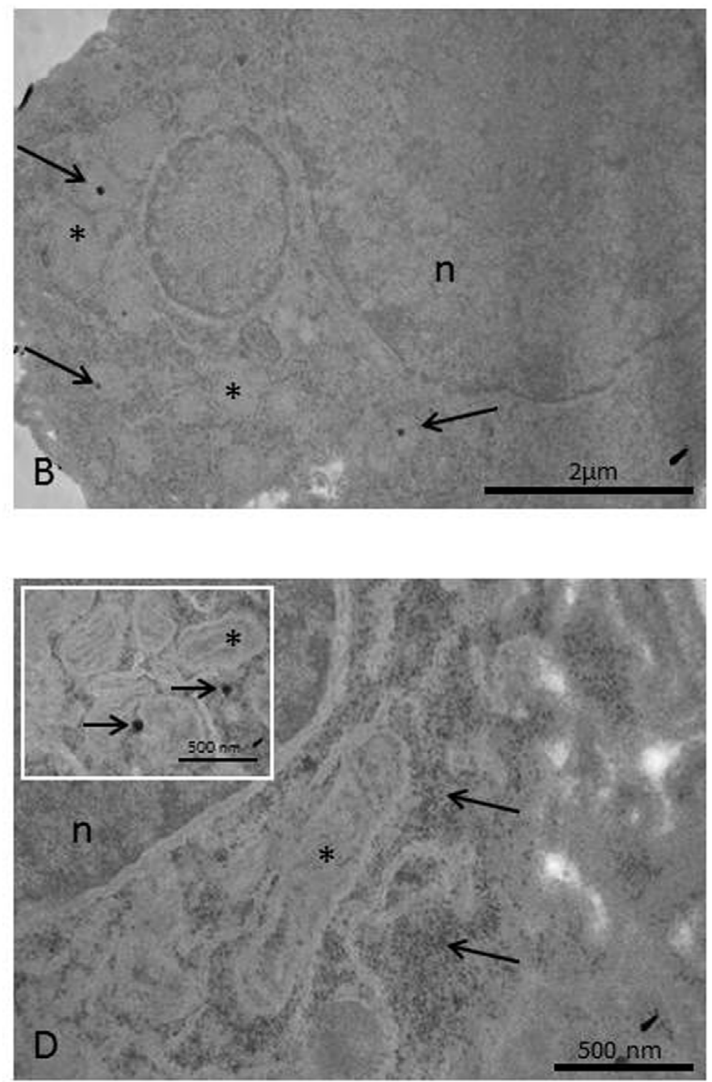

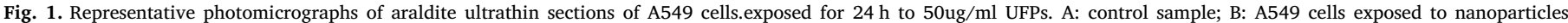

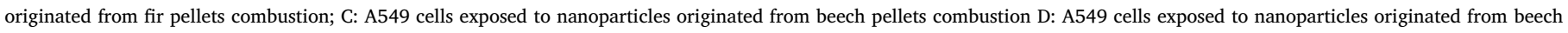
wood combustion. Asterisks: mitochondria; n: nuclei; arrows: nanoparticles. bar (A-C bar $=2 \mu \mathrm{m} \mathrm{D} \mathrm{bar}=200 \mathrm{~nm}$ ).

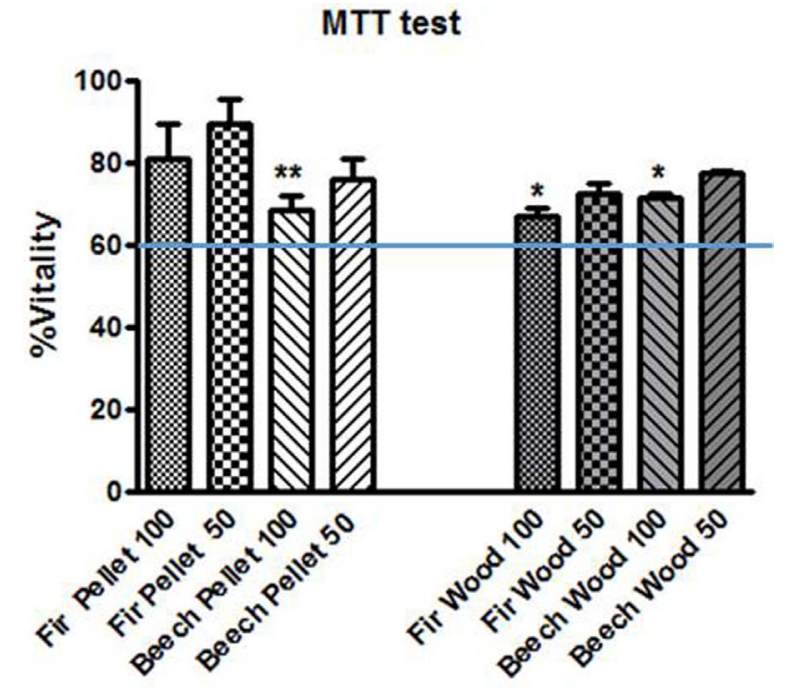

Fig. 2. The A549 cellular vitality, expressed as percentages of MTT reduction compared to the control $100 \%$, after treatments of $24 \mathrm{~h}$ with pellet and wood UFPs. Vitality of $60 \%$ is accepted for subsequent tests.

was higher for pellets samples and seemed related to the elemental content of UFP (especially Al). RNS formation (after $10 \mathrm{~min}$ ), though giving significantly different values between the investigated cases, did not provide any apparent trend neither for the type of appliances nor for the wood type.

The toxicological responses were assessed considering also the energy and environmental performance of the appliances, which actually determine the emissions and consequently the exposure in the ambient.

\section{Tail length}

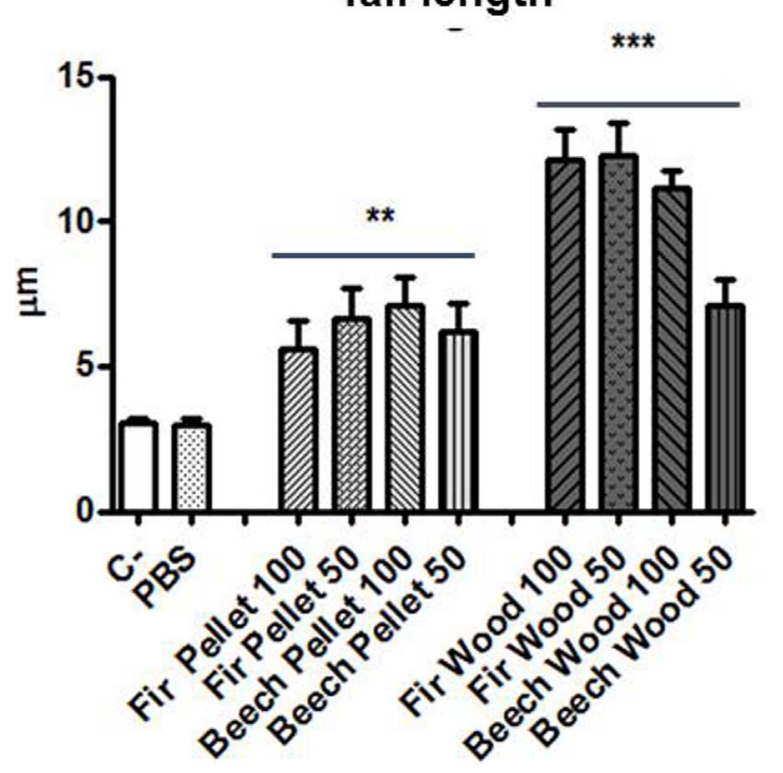

Fig. 3. Alkaline comet test evaluated as Tail lenght after treatments of A549 cells for $24 \mathrm{~h}$ with pellet and wood UFPs $* * \mathrm{p}<0.01$ vs control $* * * \mathrm{p}<0.001$ vs control.

This representation of data enhanced the differences observed between the investigated appliances in favour of the appliance with higher efficiency (pellet stove). Referring the data reported above to the energy output of the system revealed that the energy-weighed toxicological response of the beech wood log combustion was significantly higher (1.8-4.8 times) than the other cases investigated. This result 
N. $\operatorname{FOCI}(0.5) /$ cell

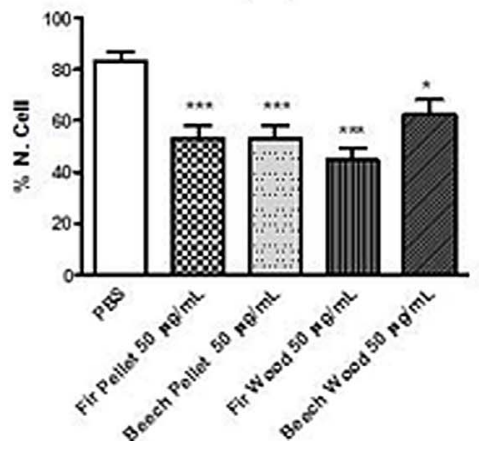

N. FOCI $(6.10) /$ cell

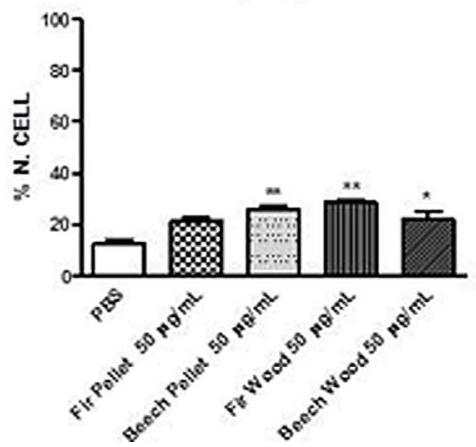

N. FOCI $(>10) /$ cell

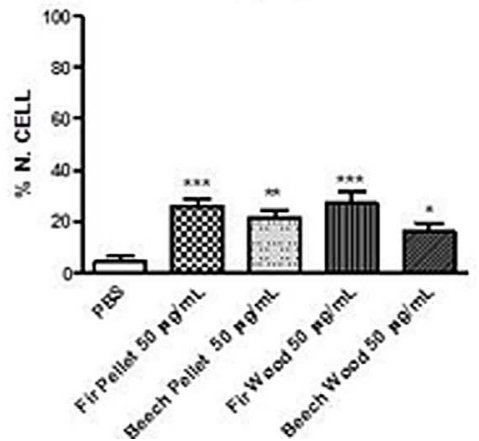

Fig. 4. Evaluation of the genotoxicity through the classification of $\gamma \mathrm{H} 2 \mathrm{AX}$ foci (\% cells with foci), after treatments of $24 \mathrm{~h}$ with pellet and wood UFPs.
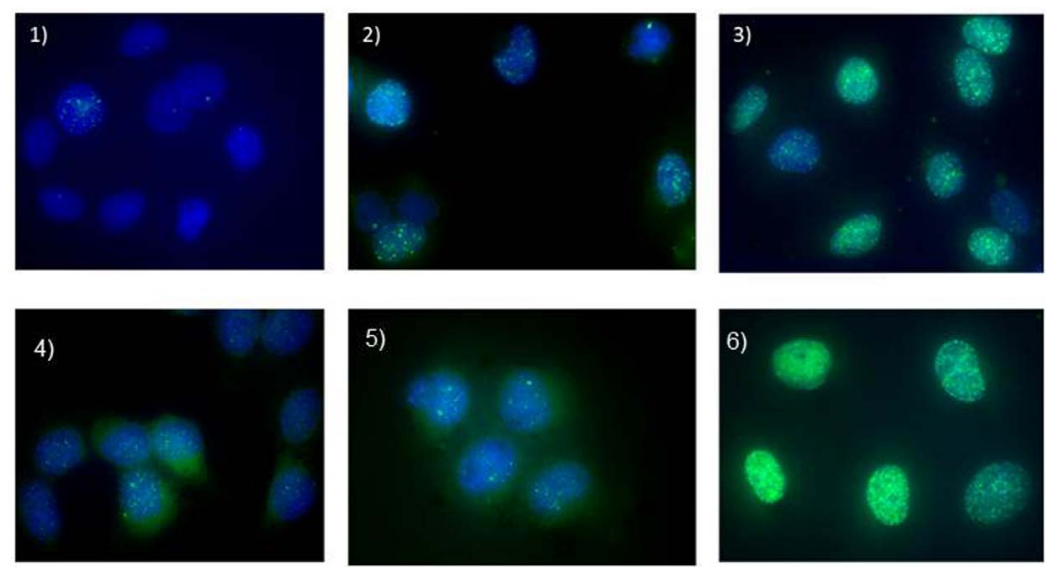

Fig. 5. DNA damage evaluated by $\mathrm{\gamma H} 2 \mathrm{AX}$ test after treatments of A549 cells for $24 \mathrm{~h}$ with pellet and wood UFPs $(50 \mu \mathrm{g} / \mathrm{mL}) 1$ Control; 2 Beech wood; 3 Fir wood; 4 Beech Pellet; 5 Fir Pellet; 6 Positive Control: Mitomycin c $0.5 \mu \mathrm{g} / \mathrm{mL}$.
ROS $\%$

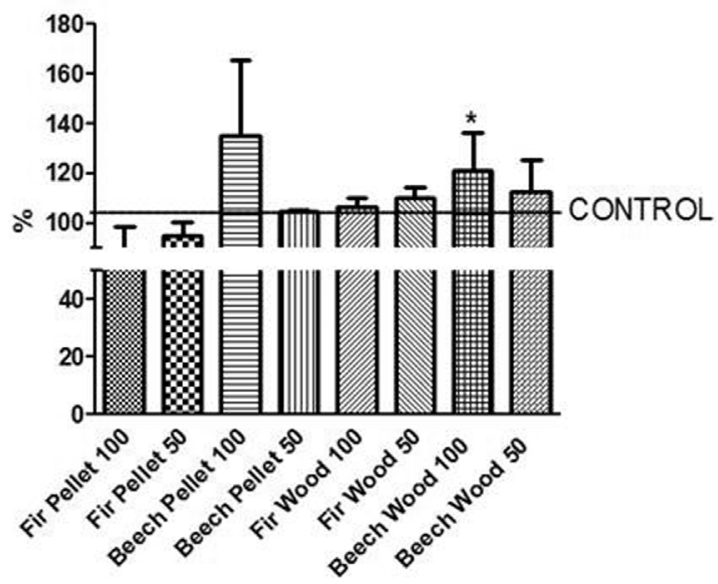

RNS $\%$

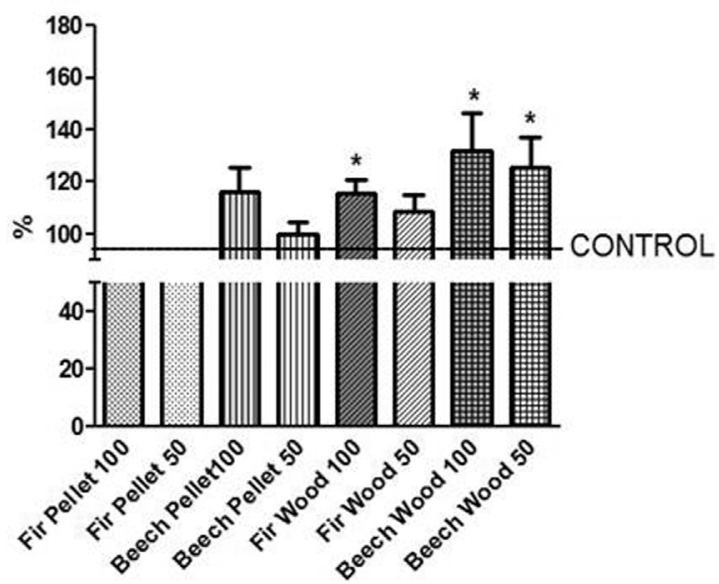

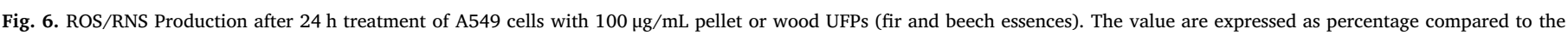
control value $(100 \%)$.

highlighted the increased DNA damage risk for exposures to the emissions of combustion of high ash content fuels in batch-wise appliances.

\section{Discussion}

The literature data on the toxicity of particles resulting from biomass combustion are sometimes difficult to compare. The most significant differences in the experiments are related to combustion conditions affecting the properties of the UFPs emitted as well as to the various wood types used $[27,28]$. The particles used for our experiments were peculiar for the size $(<100 \mathrm{~nm})$ and because they were emitted from the combustion of pellets and firewood of fir and beech.
The present work demonstrated that all types UFPs emitted by woody biomass combustion were taken up by A549 cells in the $24 \mathrm{~h}$ of treatment. Furthermore, in agreement with other authors, it was shown that the presence of serum in the treatment medium may ease the entrance in the cells, because protein corona stabilizes UFPs in medium, facilitating the translocation in cytoplasm $[15,29]$.

We observed that all the UFPs after $24 \mathrm{~h}$ of treatment elicited DNA damage, as shown both by alkaline comet test (SSBs, alkali labile and apurinic sites), and by the evaluation of the phosphorylated sites identified with the gamma-H2AX test (DSBs). Already at a $50 \mu \mathrm{g} / \mathrm{mL}$ concentration it was evident a maximum damage not associated with an increase of cytotoxicity. The fir wood log UFPs determined the most 
RNS

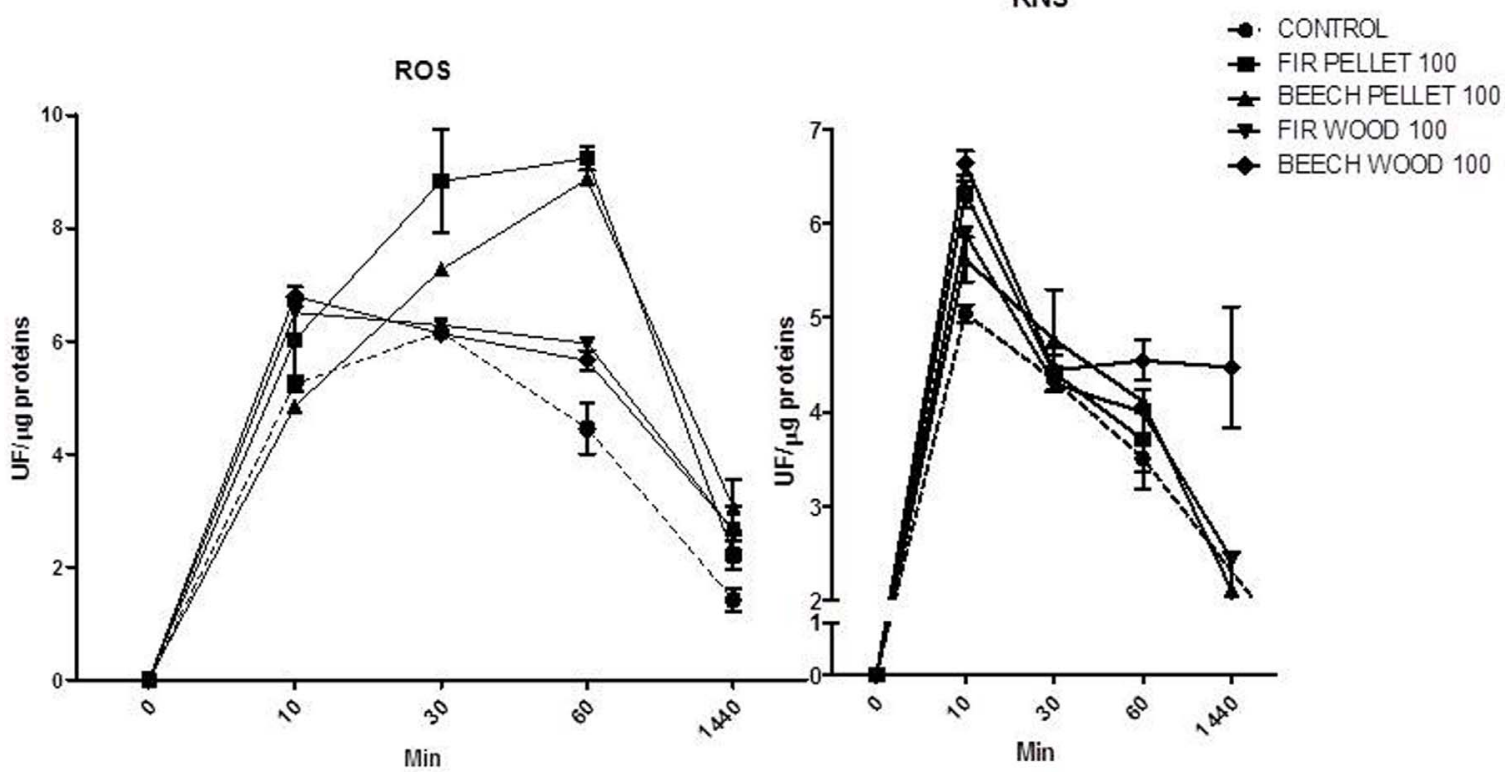

Fig. 7. Kinetics of ROS/RNS formation in A549 cells with $100 \mu \mathrm{g} / \mathrm{mL}$ pellet and wood UFPs (fir and beech essences).

Table 3

Mass dose based and energy-weighed relative toxicological responses. The lowest response in each investigated parameter is indicated with 1.

\begin{tabular}{llllll}
\hline appliance. & genotoxicity & genotoxicity & oxidative & oxidative & cytotoxicity \\
( $\mathrm{HH} 2 \mathrm{AX})$ & (comet test) & $\begin{array}{l}\text { stress } \\
\text { (ROS) }\end{array}$ & $\begin{array}{l}\text { stress } \\
\text { (RNS) }\end{array}$ & (MTT) \\
& & & &
\end{tabular}

\begin{tabular}{llllll}
\hline \multicolumn{7}{l}{ Mass dose } & based relative & \multicolumn{5}{l}{ roxicological responses } \\
FP & 1.6 & 1.1 & 1.6 & 1.1 & 1 \\
BP & 1.3 & 1 & 1.6 & 1 & 2.3 \\
FW & 1.7 & 2 & 1.1 & 1.1 & 2.6 \\
BW & 1 & 1.1 & 1 & 1.2 & 2.1 \\
\multicolumn{7}{l}{ Energy-weighed relative } & toxicological responses & & \\
FP & 1.4 & 1.3 & 1.3 & 1.3 & 1 \\
BP & 1 & 1 & 1 & 1 & 2 \\
FW & 1.8 & 2.9 & 1 & 1.5 & 3.2 \\
BW & 2 & 3.1 & 1.8 & 3.2 & 4.8
\end{tabular}

significant increase of DNA damage, while there were no differences in evaluating the number of phosphorylated foci correlated with the type of UFP.

The alteration of the cellular redox status was the possible cause of DNA damage: ROS and RNS were probably generated directly by the particle surface in short times but also as secondary process due to inflammatory response.

In a previous paper [16], we demonstrated that the pro-inflammatory component expressed as the production of IL-8 appeared to be less important in lung epithelial cells A549 compared to the monocyte cell line THP-1 cells. Although human lung cells were less sensitive, it was evident a greater effect with wood log UFPs compared to pellet UFPs. In literature, there are few reports showing a possible correlation with these pyrolytic products and inflammatory and toxic effects [28-30].

There are also indications that the pyrolysate of carbohydrates possess tumor initiating activity in the two-stage mouse skin carcinogenesis model [31]. The literature data report strong association between reactive oxygen species production and concentrations of galactosan, levoglucosan and potassium of wood smoke of particles $[28,30]$.

But the fact that the genotoxicity and the related inflammatory potential does not correlate well in vitro experiments, implies that factors determining the two situations are different [16,32]. An important consideration in the genotoxicity assessment is the presence of genotoxic molecules such as PAHs. The UFPs generated from batchwise room heater shows definitely a much higher PAH fraction than the UFPs from pellet combustion. These compounds may contribute to DNA damage by different mechanisms. The PAHs and their metabolites are known to induce the formation of bulky DNA adductors and to cause oxidative DNA damage by radical generating capacity. Furthermore, many PAHs are reported to be ligands for the aryl hydrocarbon receptor (AhR), a transcription factor involved in the regulation of the bioactivating enzymes participating in the detoxification and in their bioactivation to genotoxic metabolites [32,33].

In conclusion, the present study showed that UFP samples induced significant genotoxic effect on human lung epithelial cells (A549). In all the appliance and fuel type combinations investigated, the study of the UFP chemical composition suggested a combined effect of anhydrosugars (especially levoglucosan), elemental content (especially $\mathrm{Fe}$, $\mathrm{Al}$ ) and PAHs on the observed effects. The combustion of firewood in batch-wise appliances in general, and the use of high ash content woods in particular cause increased relative (i.e., referred to unit thermal energy output) genotoxic potential. In addition, we showed that the energy weighed relative potential would be more representative of particulate exposures than the reference to an equal mass dose of UFPs.

\section{Conflict of interest}

The authors have no conflict of interest to declare.

\section{Appendix A. Supplementary data}

Supplementary data associated with this article can be found, in the online version, at http://dx.doi.org/10.1016/j.mrgentox.2017.06.001.

\section{References}

[1] J. Jokiniemi, K. Hytönen, J. Tissari, I. Obernberger, T. Brunner, G. Bärnthaler, J. Friesenbichler, R.O. Salonen, M.-R. Hirvonen, P. Jalava, A. Pennanen, M. Happo, M. Vallius, P. Markkanen, Biomass Combustion in Residential Heating: Particulate Measurements, Sampling, and Physicochemical and Toxicological Characterisation, Univ. KUOPIO Dep. Environ. Sci. Fine Part. Aerosol Technol. Lab, 2008 (Accessed March 3, 2017), http://www.bios-bioenergy.at/uploads/media/PaperObernberger-Biomass-Combustion-in-Residential-Heating-2008-01-01.pdf.

[2] A. Kocbach Bølling, J. Pagels, K.E. Yttri, L. Barregard, G. Sallsten, P.E. Schwarze, C. Boman, Health effects of residential wood smoke particles: the importance of 
combustion conditions and physicochemical particle properties, Part. Fibre Toxicol. 6 (2009) 29, http://dx.doi.org/10.1186/1743-8977-6-29.

[3] A.G. Russell, B. Brunekreef, A focus on particulate matter and health, Environ. Sci. Technol. 43 (2009) 4620-4625, http://dx.doi.org/10.1021/es9005459.

[4] M. Sehlstedt, R. Dove, C. Boman, J. Pagels, E. Swietlicki, J. Löndahl, R. Westerholm, J. Bosson, S. Barath, A.F. Behndig, J. Pourazar, T. Sandström, I.S. Mudway, A. Blomberg, Antioxidant airway responses following experimental exposure to wood smoke in man, Part. Fibre Toxicol. 7 (2010) 21, http://dx.doi.org/10.1186/ 1743-8977-7-21.

[5] L.P. Naeher, M. Brauer, M. Lipsett, J.T. Zelikoff, C.D. Simpson, J.Q. Koenig, K.R. Smith, Woodsmoke health effects: a review, Inhal. Toxicol. 19 (2007) 67-106, http://dx.doi.org/10.1080/08958370600985875.

[6] G. Norris, S.N. YoungPong, J.Q. Koenig, T.V. Larson, L. Sheppard, J.W. Stout, An association between fine particles and asthma emergency department visits for children in Seattle, Environ. Health Perspect. 107 (1999) 489-493, http://dx.doi. org $/ 10.2307 / 3434632$.

[7] L. Barregard, G. Sällsten, P. Gustafson, L. Andersson, L. Johansson, S. Basu, L. Stigendal, Experimental exposure to wood-smoke particles in healthy humans: effects on markers of inflammation, coagulation, and lipid peroxidation, Inhal. Toxicol. 18 (2006) 845-853, http://dx.doi.org/10.1080/08958370600685798.

[8] P.H. Danielsen, S. Loft, A. Kocbach, P.E. Schwarze, P. Muller, Oxidative damage to DNA and repair induced by Norwegian wood smoke particles in human A549 and THP-1 cell lines, Mutat. Res. - Genet. Toxicol. Environ. Mutagen. 674 (2009) 116-122, http://dx.doi.org/10.1016/j.mrgentox.2008.10.014.

[9] P.-L. Liu, Y.-L.Y.-H. Chen, Y.-L.Y.-H. Chen, S.-J. Lin, Y.R. Kou, Wood smoke extract induces oxidative stress-mediated caspase-independent apoptosis in human lung endothelial cells: role of AIF and EndoG, Am. J. Physiol. Lung Cell. Mol. Physiol. 289 (2005) L739-L749, http://dx.doi.org/10.1152/ajplung.00099.2005.

[10] S. Salvi, S.T. Holgate, Mechanisms of particulate matter toxicity, Clin. Exp. Allergy 29 (1999) 1187-1194, http://dx.doi.org/10.1046/j.1365-2222.1999.00576.x.

[11] E. Corsini, S. Budello, L. Marabini, V. Galbiati, A. Piazzalunga, P. Barbieri, S. Cozzutto, M. Marinovich, D. Pitea, C.L. Galli, Comparison of wood smoke PM2.5 obtained from the combustion of FIR and beech pellets on inflammation and DNA damage in A549 and THP-1 human cell lines, Arch. Toxicol. 87 (2013) 2187-2199, http://dx.doi.org/10.1007/s00204-013-1071-z.

[12] L. Barregard, G. Sallsten, L. Andersson, A.-C. Almstrand, P. Gustafson, M. Andersson, A.-C. Olin, Experimental exposure to wood smoke: effects on airway inflammation and oxidative stress, Occup. Environ. Med. 65 (2008) 319-324, http://dx.doi.org/10.1136/oem.2006.032458.

[13] P.H. Danielsen, E.V. Bräuner, L. Barregard, G. Sällsten, M. Wallin, R. Olinski, R. Rozalski, P. Møller, S. Loft, Oxidatively damaged DNA and its repair after experimental exposure to wood smoke in healthy humans, Mutat. Res. - Fundam. Mol. Mech. Mutagen. 642 (2008) 37-42, http://dx.doi.org/10.1016/j.mrfmmm.2008. 04.001

[14] G. Sällsten, P. Gustafson, L. Johansson, S. Johannesson, P. Molnár, B. Strandberg, C. Tullin, L. Barregard, Experimental wood smoke exposure in humans, Inhal. Toxicol. 18 (2006) 855-864, http://dx.doi.org/10.1080/08958370600822391.

[15] A. Muala, G. Rankin, M. Sehlstedt, J. Unosson, J.A. Bosson, A. Behndig, J. Pourazar, R. Nyström, E. Pettersson, C. Bergvall, R. Westerholm, P.I. Jalava, M.S. Happo, O. Uski, M.-R. Hirvonen, F.J. Kelly, I.S. Mudway, A. Blomberg, C. Boman, T. Sandström, Acute exposure to wood smoke from incomplete combustion-indications of cytotoxicity, Part. Fibre Toxicol. 12 (33) (2015), http://dx.doi.org/10. 1186/s12989-015-0111-7.

[16] E. Corsini, S. Ozgen, A. Papale, V. Galbiati, G. Lonati, P. Fermo, L. Corbella, G. Valli, V. Bernardoni, M. Dell'Acqua, S. Becagli, D. Caruso, R. Vecchi, C.L. Galli, M. Marinovich, Insights on wood combustion generated proinflammatory ultrafine particles (UFP), Toxicol. Lett. 266 (2016) 74-84, http://dx.doi.org/10.1016/j. toxlet.2016.12.005.

[17] J. Leskinen, J. Tissari, O. Uski, A. Virén, T. Torvela, T. Kaivosoja, H. Lamberg, I. Nuutinen, T. Kettunen, J. Joutsensaari, P.I. Jalava, O. Sippula, M.-R. Hirvonen, J. Jokiniemi, Fine particle emissions in three different combustion conditions of a wood chip-fired appliance - Particulate physico-chemical properties and induced cell death, Atmos. Environ. 86 (2014) 129-139, http://dx.doi.org/10.1016/j. atmosenv.2013.12.012.
[18] S. Ozgen, S. Cernuschi, M. Giugliano, Experimental evaluation of particle number emissions from wood combustion in a closed fireplace, Biomass Bioenergy 50 (2013) 65-74, http://dx.doi.org/10.1016/j.biombioe.2013.01.015.

[19] S. Ozgen, S. Caserini, S. Galante, M. Giugliano, E. Angelino, A. Marongiu, F. Hugony, G. Migliavacca, C. Morreale, Emission factors from small scale appliances burning wood and pellets, Atmos. Environ. 94 (2014) 144-153, http://dx.doi. org/10.1016/j.atmosenv.2014.05.032.

[20] S. Ozgen, S. Becagli, V. Bernardoni, S. Caserini, D. Caruso, L. Corbella, M. Dell'Acqua, P. Fermo, R. Gonzalez, G. Lonati, S. Signorini, R. Tardivo, E. Tosi, G. Valli, R. Vecchi, M. Marinovich, Analysis of the chemical composition of ultrafine particles from two domestic solid biomass fired room heaters under simulated real-world use, Atmos. Environ. 150 (2017) 87-97, http://dx.doi.org/10.1016/j. atmosenv.2016.11.048.

[21] E. Corsini, R. Vecchi, L. Marabini, P. Fermo, S. Becagli, V. Bernardoni, D. Caruso, L. Corbella, M. Dell'Acqua, C.L. Galli, G. Lonati, S. Ozgen, A. Papale, S. Signorini, R. Tardivo, G. Valli, M. Marinovich, ultrafine particles chemical composition and biological effects: ambient air measurements at an alpine town impacted by wood burning, Sci. Total Environ. 587 (2017) 223-231.

[22] N.P. Singh, M.T. McCoy, R.R. Tice, E.L. Schneider, A simple technique for quantitation of low levels of DNA damage in individual cells, Exp. Cell Res. 175 (1988) 184-191, http://dx.doi.org/10.1016/0014-4827(88)90265-0.

[23] K. Wischermann, S. Popp, S. Moshir, K. Scharfetter-Kochanek, M. Wlaschek, F. de Gruijl, W. Hartschuh, R. Greinert, B. Volkmer, a Faust, a Rapp, P. Schmezer, P. Boukamp, UVA radiation causes DNA strand breaks, chromosomal aberrations and tumorigenic transformation in HaCaT skin keratinocytes, Oncogene 27 (2008) 4269-4280, http://dx.doi.org/10.1038/onc.2008.70.

[24] H. Wang, J.A. Joseph, Quantifying cellular oxidative stress by dichlorofluorescein assay using microplate reader, Free Radic. Biol. Med. 27 (1999) 612-616, http://dx. doi.org/10.1016/S0891-5849(99)00107-0.

[25] J.S. Carroll, C.J. Ku, W. Karunarathne, D.M. Spence, Red blood cell stimulation of platelet nitric oxide production indicated by quantitative monitoring of the communication between cells in the bloodstream, Anal. Chem. (2007), http://dx.doi. org/10.1021/ac0706271.

[26] R.J. Lowry, O. Randall, Protein measurement with the Folin phenol reagent, Readings 193 (1951) 265-275, http://dx.doi.org/10.1016/0304-3894(92)87011-4.

[27] C. Alves, C. Gonçalves, A.P. Fernandes, L. Tarelho, C. Pio, Fireplace and woodstove fi ne particle emissions from combustion of western Mediterranean wood types, Atmos. Res. 101 (2011) 692-700, http://dx.doi.org/10.1016/j.atmosres.2011.04. 015.

[28] B. Vu, C.A. Alves, C. Gonçalves, C. Pio, F. Gonçalves, R. Pereira, Mutagenicity assessment of aerosols in emissions from wood combustion in Portugal, Environ. Pollut. 166 (2012) 172-181, http://dx.doi.org/10.1016/j.envpol.2012.03.005.

[29] S. Barillet, M.-L. Jugan, M. Laye, Y. Leconte, N. Herlin-Boime, C. Reynaud, M. Carrière, In vitro evaluation of SiC nanoparticles impact on A549 pulmonary cells: cyto-, genotoxicity and oxidative stress, Toxicol. Lett. 198 (2010) 324-330, http://dx.doi.org/10.1016/j.toxlet.2010.07.009.

[30] S.H. Hamad, J.J. Schauer, D.S. Antkiewicz, M.M. Shafer, A.K.H. Kadhim, ROS production and gene expression in alveolar macrophages exposed to PM2.5 from Baghdad, Iraq: seasonal trends and impact of chemical composition, Sci. Total Environ. 543 (2016) 739-745, http://dx.doi.org/10.1016/j.scitotenv.2015.11.065.

[31] A. Saffari, N. Daher, M.M. Shafer, J.J. Schauer, C. Sioutas, Seasonal and spatial variation of trace elements and metals in quasi-ultrafine (PM0.25) particles in the Los Angeles metropolitan area and characterization of their sources, Environ. Pollut. 181 (2013) 14-23, http://dx.doi.org/10.1016/j.envpol.2013.06.001.

[32] J.-H. Park, D. Mangal, K.A. Tacka, A.M. Quinn, R.G. Harvey, I.A. Blair, T.M. Penning, Evidence for the aldo-keto reductase pathway of polycyclic aromatic trans-dihydrodiol activation in human lung A549 cells, Proc. Natl. Acad. Sci. U. S. A. 105 (2008) 6846-6851, http://dx.doi.org/10.1073/pnas.0802776105.

[33] Z. Andrysik, J. Vondracek, S. Marvanova, M. Ciganek, J. Neca, K. Pencikova, B. Mahadevan, J. Totinka, W.M. Baird, A. Kozubik, M. Machala, Activation of the aryl hydrocarbon receptor is the major toxic modeof action of an organic extract of a reference urban dust particulatematter mixture: the role of polycyclic aromatic hydrocarbons, Mutat. Res. 714 (2011) 53-62. 